\title{
Influence of $p H$ on the Dehydrogenase Activity in Fusarium graminearum Species Schwb. Telemorph Gibberella Zeae (Schwb.) Petsch) Production of Mycotoxins
}

\author{
PETRONELA GRADINARIU ${ }^{1}$, MARGARETA GRUDNICKI², IOAN-MARIAN RISCA ${ }^{2 *}$, \\ VIOLETA MANGALAGIU ${ }^{3 *}$ \\ ${ }^{1}$ INDCSB, Biological Research Institute, 47 Lascar Catargi Str., 700107, Iasi, Romania \\ ${ }^{2}$ Stefan cel Mare University of Suceava, Forestry Faculty, 13 Universitatii Str., 720119, Suceava, Romania, \\ ${ }^{3}$ Alexandru Ioan Cuza University of Iasi, CERNESIM Research Center, 11 Carol Blvd., 700506, Iasi, Romania
}

\begin{abstract}
Dehydrogenases are enzymes that catalyzes the electron transfer reactions and act according to their redox potential ( $r H)$ from negative $r H$ values to the highest positive ones. Depending on the chemical nature of the substrate which donates hydrogen, dehydrogenase bear appropriate names: $\alpha$-ketoglutarate glucoso 6-fosfat dehidrogenase, isocitrate dehydrogenase, malate dehydrogenase, etc. The paper presents the influence of pH against the dehydrogenase activity, both if the mycelium and culture liquid, at 21 and 28 days from the inoculation.
\end{abstract}

Keywords: oxidoreductase, dehydrogenase, enzymes

The $p \mathrm{H}$ values, necessary for the growth of micro-organisms or for the production of certain substances biologically active ingredients, are parameters to be treated in the studies on the biology of the mold.

Most of the micro-organisms grows at $p \mathrm{H}$ values between 5 to 9 , between these extremes each has an optimal $\mathrm{pH}$ of action [1]. Previously, the effect of $p \mathrm{H}$ carried out on the activity of oxidoreductazes were studied on other species, such as: Aspergillus niger and Aspergillus tereus species, (Trichoderma viride, Mirothecium verrucaria [2], Chaetomium globosum [3-5].

Studies on the effect of $p \mathrm{H}$ on the activity of enzymes at the level of the patosystem (Triticum aestivum-Fusarium graminearum) are few [6], establishing that the fungus needs for growing and developing $p \mathrm{H}$ values between 6 and 10. Fusarium graminearum requires, like all living organisms, chemical compounds necessary for the synthesis of cellular constituents, for the activity of enzymes and transport systems and for the energy supply of the entire organism $[7,8]$. The paper wants to highlight the influences of nature of hydrogen donor substrate and the $p \mathrm{H}$ against the enzymatic activity.

\section{Experimental part}

The determinations were made from the mycelium's biomass resulting after the centrifugation of culture media. The determination method is based on the dehydrogenases capacity to transfer hydrogen from various substrates to the solution of 2,3,5-triphenyl tetrazolium chloride (TTC) which is reduced to red colored TTC formazan. The intensity of the color is proportional to the dehydrogenases concentration.

For the dehydrogenases determination with exogenous substrate, samples have been maintained at a temperature of $28^{\circ} \mathrm{C}$ for $17 \mathrm{~h}$. As exogenous substrate, solutions of known normality of glucose [9-11], natrium isocytrate [12, 13], $\alpha$ ketoglutaric acid [14] and malate dehydrogenase $[15,16]$ were used. The color intensity of the TTC formazan was measured with a Perkin Elmer spectrophotometer.

The enzyme activity was expressed as the amount of the resulting formazan, following the dehydrogenase action reported to the quantity of biological material of analysed (mycelium) [17]. The $p \mathrm{H}$ variations in the Fusarium graminearum culture media were studied in a range between 2.0 and 9.0. The Brown culture media was adjusted using $\mathrm{NaOH} 1 \mathrm{~N}$ and $\mathrm{HCl} 0.1 \mathrm{~N}$. The determinations of biochemical parameters have been made at 21 and 28 days from seeding, in fungal mycelium and culture fluid. Al the date was expressed as $\mu \mathrm{g}$ formazan $\mathrm{g}$ biological material. The data were statistically interpreted with the Student $t$ test and the Pearson correlation coefficient ( $r$ ), in order to determine whether there is an association between the two variables ( $p \mathrm{H}$ and oxidoreductases activity) and how strong this association is [18].

*email: risca@usv.ro; violetaren@yahoo.com 


\section{Results and discussions}

The activity of glucose 6-phosphate dehydrogenase in mycelium under the influence of $p \mathrm{H}$ are shown in the figure 1. Thus, after 21 days from the inoculation, the highest value of the activity glucozo 6-phosphate dehydrogenase has been recorded at $p \mathrm{H} 9(0,0066 \mu \mathrm{g} / \mathrm{g})$., followed by $p \mathrm{H} 4(0,0044 \mu \mathrm{g} / \mathrm{g})$, a.s.o. The lowest values were recorded at $p \mathrm{H} 2$ and $p \mathrm{H} 3(0,0012 \mu \mathrm{g} / \mathrm{g}$ and $0,0011 \mu \mathrm{g} / \mathrm{g}$, respectively) .

After 28 days from inoculation, the greatest enzyme activity has been recorded at $p \mathrm{H} 7(0,0122 \mu \mathrm{g} / \mathrm{g})$, and the lowest value of the enzyme activity has been recorded at $p \mathrm{H} 2(0,0014 \mu \mathrm{g} / \mathrm{g})$.

Following the dynamic in the activity of this enzyme there is evidence of an increase in the second period of study (at 28 days from inoculation) compared to the first period of time at most of the variants of work.

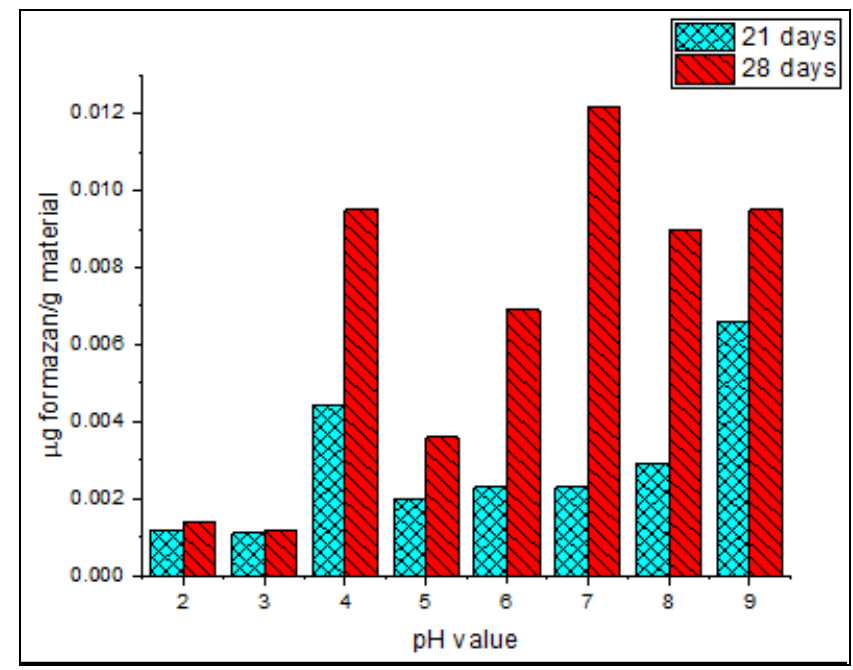

Fig. 1. Effect of $p \mathrm{H}$ on the activity of the glucozo 6-phosphate dehydrogenase - mycelium

The speed of the enzymatic reactions is influenced by the $p \mathrm{H}$ of the culture media, its campaign as a general rule, within a narrow range of $p \mathrm{H}$, bearing the name of the optimum $p \mathrm{H}$ of action [19], a statement confirmed, in general, also in our results; the optimum $p \mathrm{H}$ of the glucozo 6-phosphate dehydrogenase activity is 8,5. Following of the activity of the enzyme glucozo 6-phosphate dehydrogenase under the influence of the $p \mathrm{H}$ of the contents from 2 to 9 , two time intervals (at 21 days and 28 days from inoculation), it has been found that the lowest activity has been obtained under the influence of a very acid $p \mathrm{H} \mathrm{(2} \mathrm{and} \mathrm{3),} \mathrm{and} \mathrm{the} \mathrm{highest} \mathrm{activity} \mathrm{has} \mathrm{been} \mathrm{obtained} \mathrm{for} \mathrm{a} p \mathrm{H}$ value close to the optimum $p \mathrm{H}$ value $(p \mathrm{H} 8.5)$.

The results on the effect of $p \mathrm{H}$ on the activity of the isocitrate dehydrogenase in mycelium are shown in the figure 2. 21 days after the inoculation the highest activity has been recorded at $p \mathrm{H} 5(0,0157 \mu \mathrm{g} / \mathrm{g})$ and the lowest at $p \mathrm{H} 3$ $(0,0012 \mu \mathrm{g} / \mathrm{g})$.

After 28 days, the lowest value of the activity of the isocitrate dehydrogenase has been recorded at $p \mathrm{H} 5(0,0045$ $\mu \mathrm{g} / \mathrm{g})$ and the highest activity of the enzyme at $p \mathrm{H} 8(0,0955 \mu \mathrm{g} / \mathrm{g})$.

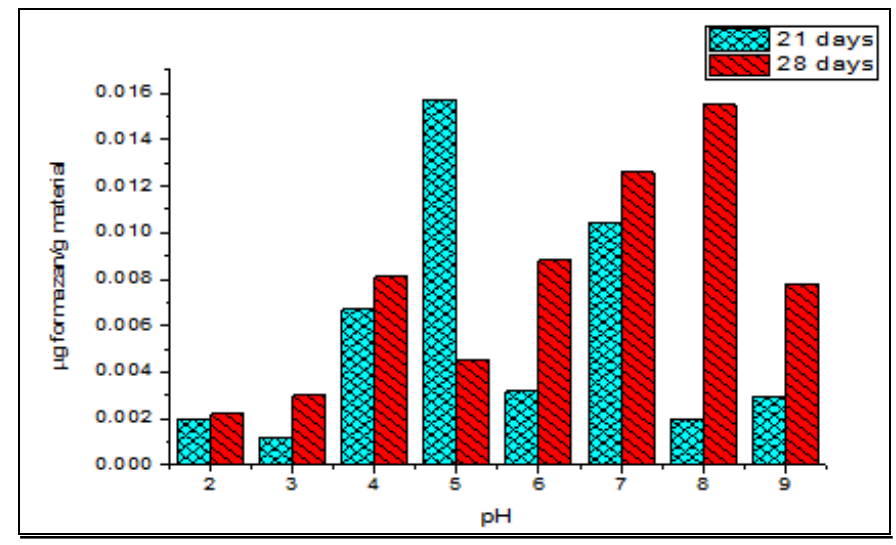

Fig. 2. Effect of $p \mathrm{H}$ on the activity of the isocitrate dehydrogenase mycelium

The activity of the isocitrate dehydrogenase under the influence of the various $p \mathrm{H}$ values (2-9) on the two periods of time taken in the study, indicates a poor correlation with the $p \mathrm{H}$ of the environment; in 28 days after the 
inoculation, the maximum value of the activity of the isocitrate dehydrogenase has been recorded on the variant with

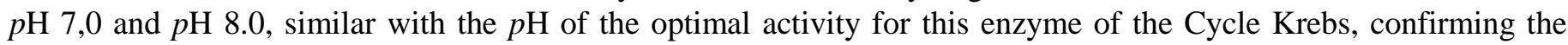
results obtained by other authors [6].

All these data show that the activity of the $\alpha$-ketoglutarate dehydrogenase from both the time intervals concerned (21 and 28 days after the inoculation) had a higher value on the environment with $p \mathrm{H} \mathrm{7,0}$ results that support and the data obtained from the other species of fungi under the influence of the same factor, which shows that the activity of the enzyme may be optimal at a neutral $p \mathrm{H}[5,20]$.

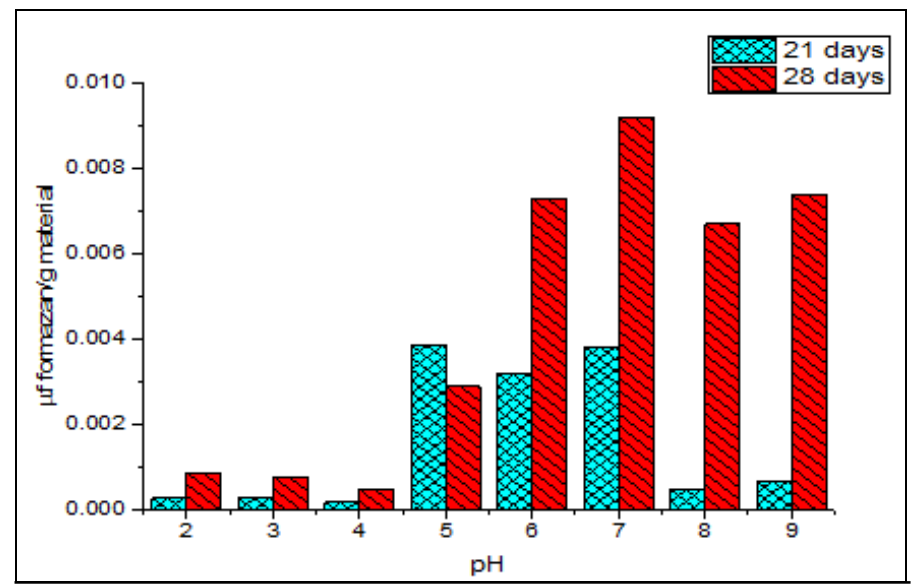

Fig. 3. Effect of $p \mathrm{H}$ on the activity of $\alpha$-ketoglutarate dehydrogenase mycelium

The results concerning the activity of malate dehydrogenase in miceliul finial under the influence of $p \mathrm{H}$ are shown in the figure 4. At 21 days of from the inoculation, the highest value of the activity of the enzyme has been recorded at $p \mathrm{H} 5,0(0,0118 \mu \mathrm{g} / \mathrm{g})$ and the lowerst enzyme activity at $p \mathrm{H} 2(0,0016 \mu \mathrm{g} / \mathrm{g})$.

After 28 days from inoculation it has been found that the lowest activity of the enzyme has been recorded at $p \mathrm{H} 2,0$ $(0,0020 \mu \mathrm{g} / \mathrm{g})$, followed, in ascending order, by $0,0026 \mu \mathrm{g} / \mathrm{g}(p \mathrm{H} \mathrm{3,0}), 0,0031 \mu \mathrm{g} / \mathrm{g}(p \mathrm{H} \mathrm{4,0}), 0,0039 \mu \mathrm{g} / \mathrm{g}(p \mathrm{H} 9,0)$, $0,0070 \mu \mathrm{g} / \mathrm{g}(p \mathrm{H} 8,0), 0,0077 \mu \mathrm{g} / \mathrm{g}(p \mathrm{H} 6,0), 0,0090 \mu \mathrm{g} / \mathrm{g}(p \mathrm{H} 5,0)$ and $0,0094 \mu \mathrm{g} / \mathrm{g}(p \mathrm{H} \mathrm{7,0)}$.

Following the dynamic in the activity of malate dehydrogenase dehydrogenase it has been found that, after 28 days from inoculation, compared with the first 21 days, the values of the enzyme activity decreased (figure 4).

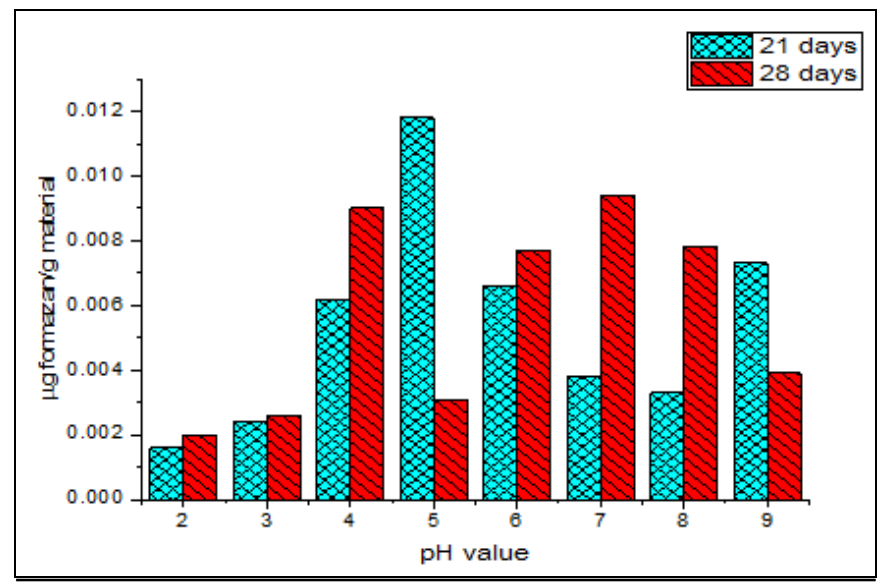

Fig. 4. Effect of $p \mathrm{H}$ on the activity of malate dehydrogenase -mycelium-

At $p \mathrm{H}$ values of 2, 3 and 4, the activity of this enzyme had small values at both 21 and 28 days from inoculation, while the values recorded on the medium with $\mathrm{pH} 5,0-p \mathrm{H} \mathrm{9,0}$ activities were significantly higher.

\section{Conclusions}

The analysis of the obtained results in the dynamics of Krebs Cycle's dehydrogenases (at 21 and 28 days after inoculation), indicates that the $p \mathrm{H}$ variation, influenced in different ways metabolic activity, namely acid $\mathrm{pH}$ values has led to a sharp drop in the enzymatic semnificatica values, whereas values of $p \mathrm{H}$ around neutral stimulated the studied biochemical parameters.

The calculus of Pearson's correlation coefficient (r) between the enzymes acivity and the $\mathrm{pH}$ values indicates that the metabolic activity of the fungus Fusarium graminearum, has a precise tolerance interval. 
Thus, in the case of glucose 6-phosphate dehydrogenase, at 21 days the correlation was poor $(\mathrm{r}=0.436)$, as opposed to the interval of 28 days when the correlation was high $(\mathrm{r}=0.756)$.

In the case of isocitrate dehydrogenase, at 21 days the correlation was nule $(r=0.050)$, as opposed to the interval of 28 days when the correlation was high $(\mathrm{r}=0.756)$.

The $\alpha$-ketoglutarate dehydrogenase had a nule correlation at 21 days $(r=0.230)$ and a high correlation at 28 days $(r$ $=0.874$ ).

For the malate dehydrogenase the Pearson correlation coefficient was nule at 21 days $(0.282)$ and moderate at 28 days (0.539). All the data were calculated for a signification level of 0.01 .

\section{References}

1.EISENTHAL, R., DANSON, M. J. (Eds.), Enzyme Assays. A Practical Approach. Second Edition. Oxford University Press, 2002 , p. 36.

2.ZAMFIRESCU, I., GOMOIU, I. Al-V-lea, Simpozion de Microbiologie Industriala si Biotehnologie, Iasi, 1986, p. 189.

3.MANOLIU, A., GRADINARIU, P. Roum. Biotechnol. Lett., 5, 2007, p. 3415.

4MANOLIU, AL., OPRICA, L., BODALE, I., Al X-lea Simpozion de Microbiologie si Biotehnologie, Iasi, 2004 , p.332.

5.OPRICA-ANTOHE, L., Teza de doctorat, Iasi, 2005, p. 51.

6.PEKKARINEN, A. I ., MANNONEN L., JONES, B. L., NIKU- PAAVOLA, M. L., J. Cereal Sci., 31, 2000 , p. 253.

7.MADIGAN, M. T., MARTINKO, J. M., BENDER, K. S., BUCKLEY D. H., STAHL, D. A., Brock Biology of Microorganisms, Fourteenth Ed., Pearson Education Inc., 2015, p. 79.

8.MANOLIU, A., OPRICA-ANTOHE, L., OLTEANU, Z., TANASE, A., CIORNEI, A., Al IX - lea Simpozion de Microbiologie si Biotehnologie, Iasi, 1998, p. 561.

9.TIAN, W.N., BRAUNSTEIN, L. D., PANG, J., STUHLMEIER, K. M., XI, Q.C., TIAN, X., STANTON, R., J. Biol. Chem. 273, 1998, p.10609.

10.KLETZIEN, R. F., HARRISs, P. K., FOELLMI, L. A., The FASEB Journal, 8(2), 1994, p.174.

11.CAPPELLINI, M. D., FIORELLI, G., The Lancet, 371(9606), 2008, p. 64.

12.QUARTARARO, C. E., HAZRA, S., HADI, T., BLANCHARD, J. S., Biochemistry, 52 (10), 2013 , p. 1765.

13.BEGLEY, T. P., McMURRY, J., The Organic Chemistry of Biological Pathways. Roberts and Co. Publishers, 2005, p. 189.

14.TRETTER, L., ADAM-VIZI, V., Philos. Trans. R. Soc. Lond. B Biol. Sci., 2005, 360(1464), p. 2335.

15.STARKOV, A., FISKUM, G., CHINOPOULOS, C., LORENZO, B. J., BROWNE, S.E., PATEL, M. S., BEAL, M. F., J. Neurosci., 2004, 24(36), p. 7779 .

16.GIBSON, G. E., BLASS, J. P., BEAL, M. F., BUNIK, V., Mol. Neurobiol., 2005, 31, p. 43.

17.WILSON, K., WALKER, J., Principles and Techniques of Biochemistry and Molecular Biology. Seventh Ed. Cambridge University Press, Cambridge, 2010, p. 602.

18.SELVIN, S., A Biostatistical Toolbox for Data Analysis. Cambridge University Press, New York, 2015 , p. 69.

19.BISSWANGER, H., Practical Enzymology. Second Ed. Wiley-VCH, Weinheim, 2011, p. 42.

20.MAGNELLI, P., RAMOS, M. A., FORCHIASSIN, F., Mycologia, 2, 1996, p. 249.

$\overline{\text { Manuscript received: } 25.06 .2019}$ 
